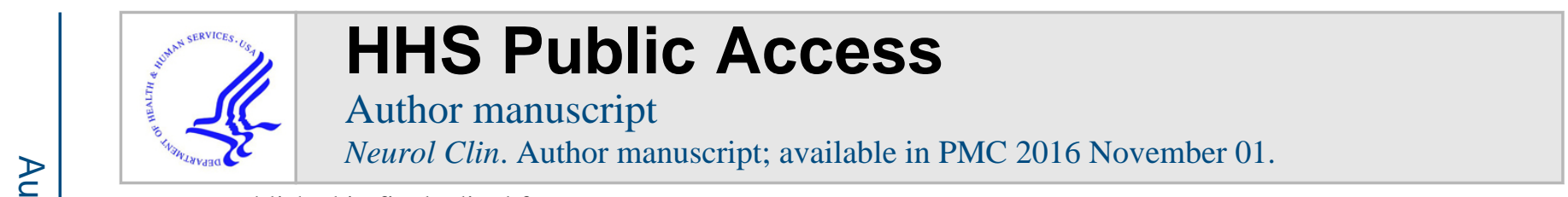

Published in final edited form as:

Neurol Clin. 2015 November ; 33(4): 807-830. doi:10.1016/j.ncl.2015.07.001.

\title{
Familial ALS
}

\author{
Kevin Boylan \\ Director, ALS Center Department of Neurology Mayo Clinic Jacksonville, Mayo Clinic, Cannaday \\ 2E Neurology, 4500 San Pablo Road, Jacksonville, FL 32224
}

Kevin Boylan: boylan.kevin@mayo.edu

\section{Synopsis}

Genes linked to ALS susceptibility are being identified at an increasing rate owing to advances in molecular genetic technology. Genetic mechanisms in ALS pathogenesis appear to exert major effects in $\sim 10 \%$ of patients, but genetic factors at some level may be important components of disease risk in most ALS patients. Identification of gene variants associated with ALS has informed concepts of the pathogenesis of ALS, aided the identification of therapeutic targets, facilitated research to develop new ALS biomarkers, and supported the establishment of clinical diagnostic tests for ALS-linked genes. Translation of this knowledge to ALS therapy development is ongoing.

\section{Key terms}

Amyotrophic lateral sclerosis; ALS; Familial ALS; Genetics; Phenotypes; Genetic testing

\section{Background}

Familial incidence of ALS was described in scattered publications beginning in the mid 1800s but received limited attention in the literature until the report in 1955 by Kurland and Mulder, which suggested that ALS may be familial in nearly $10 \%$ of cases (1-2). The application of molecular genetic techniques to ALS, marked by the report in 1993 of linkage of the superoxide dismutase 1 (SOD1) gene in familial ALS, signaled an increasing focus on genetics in ALS as a means to gain insights into the pathogenesis of the disease, identify therapeutic targets and facilitate diagnosis (3). In recent years a rapidly expanding list of genetic variations linked to ALS and their related clinical and pathological correlates continues to provide key insights into the causes of ALS and inform therapy development (4).

This review examines genetic correlates of classical ALS demonstrating combined upper and lower motor neuron signs, but some of the genes discussed may be associated with pure lower motor neuron and pure upper motor neuron phenotypes, and in some cases

\footnotetext{
Disclosures: No relevant disclosures.

Publisher's Disclaimer: This is a PDF file of an unedited manuscript that has been accepted for publication. As a service to our customers we are providing this early version of the manuscript. The manuscript will undergo copyediting, typesetting, and review of the resulting proof before it is published in its final citable form. Please note that during the production process errors may be discovered which could affect the content, and all legal disclaimers that apply to the journal pertain.
} 
frontotemporal dementia and parkinsonian features. Technological developments that have facilitated recent advances in ALS gene discovery are briefly discussed, and efforts to translate growing knowledge of ALS genetics into patient care are noted. In line with recommendations of the International Human Genome Society, DNA sequence alterations associated with disease are referred to in terms such as "genetic sequence variants" or "sequence variants" rather than "mutations," recognizing that pathogenicity of some ALSassociated gene variants is less well established than for others (5).

\section{Recent technological developments and ALS gene discovery}

Advances in molecular genetic technology and capacity for handling extensive data sets generated by large scale DNA sequencing have had significant impact on discovery of new gene mutations linked to ALS $(4,6-7)$. In addition to "first generation" methods such as genetic linkage analysis and candidate gene analysis relying on linked DNA markers in ALS pedigrees, newer approaches including genome wide association studies (GWAS) and "nextgeneration" sequencing techniques such as whole exome sequencing and whole genome sequencing have allowed the search for ALS-linked genes to be conducted in large sample sets derived mainly from patients with no family history of ALS and in families from which relatively few DNA samples may be available (6-8). GWAS optimally requires large case control sample sets, generally at least several thousand samples, and is based on the concept that variants of a given gene commonly associated with ALS may be present in a sufficient number of patients to be detectable if enough patients are studied (6). Next-generation technology leverages high-throughput, large scale parallel DNA sequencing of essentially all expressed coding sequences (whole-exome sequencing) or the entire genome (whole genome sequencing) in conjunction with software and computing capacity able to sort and align short segments of overlapping DNA sequence and efficiently analyze of the tremendous amount of sequence data produced. Whole exome or whole genome sequencing produce essentially complete data on all protein-coding genes or on the entire genetic sequence, respectively, allowing identification of wide range of potential DNA variants potentially associated with ALS (6-8).

\section{Clinical spectrum of ALS genetics}

Increasing evidence from clinical and basic research suggests that ALS has multiple causes with an important, although varied, genetic component $(4,9)$. Genetic factors in ALS range from highly penetrant ALS-linked gene variants to sequence variants with seemingly limited impact on disease susceptibility (6). Phenotypes associated with these sequence variants include classical ALS, primary lateral sclerosis (PLS), and progressive muscular atrophy (PMA) $(4,6,8)$. An important 'extramotor' feature associated with some gene variants linked to ALS is frontotemporal dementia (FTD), which may develop with, prior to, or after onset of motor signs in ALS, and as FTD alone (10-11). Less common clinical features associated with some ALS-linked gene variants include extrapyramidal features and inclusion body myopathy $(4,12)$. While familial ALS is mainly an adult-onset disorder, a few genes associated with ALS may have phenotypes characterized by juvenile onset $(6,8)$. Although some clinical patterns may tend to occur in association with specific ALS gene variants, in clinical practice significant overlap among phenotypes limits practical 
application as a means to ascertain patients likely to carry a specific ALS-linked gene variant (12).

\section{Genetic susceptibility to ALS}

ALS clinical registry data and more recent meta-analysis based on prospective population based registries suggest that up to $10 \%$ of ALS patients have a family history of ALS in a first- or second-degree relative, generally classified as familial ALS (FALS) $(8,13)$. The remaining $90 \%$ of patients with no evident family history of ALS are designated as sporadic ALS (SALS), a potentially misleading designation for several reasons. First, persons with ALS associated with a causative gene variant may lack a family history of ALS as a result of reduced penetrance or small family size. In addition, family history may be incomplete or inaccurate owing to incomplete family history, incorrect diagnoses in ancestors, or death from other causes prior to onset of ALS in relatives genetically at risk (14).

Several studies have investigated the risk of developing ALS in relatives of ALS patients in efforts to quantitate genetic contributions to ALS susceptibility. An investigation in Sweden of the relative risk of ALS in siblings and children of ALS probands that did not exclude FALS probands found a relative risk of $9.7(95 \% \mathrm{CI}=7.2-12.8)$, and two other studies, one in UK that considered only SALS patients, and a US study that included FALS and SALS patients, reported an approximately $1 \%$ risk of ALS among first degree relatives of an ALS patient (15-17). Further, estimates of the heritability of ALS, a measure of the extent of phenotypic variability that is attributable to genetic variation, provide additional evidence that genetic factors play a significant role in sporadic as well as familial ALS. In a study of identical twins that included twins with or without a history of ALS in other relatives heritability was estimated to be about $76 \%(95 \% \mathrm{CI}=60-86 \%)$ for twins with a family history of ALS, and approximately $61 \%(95 \% \mathrm{CI}=38-78 \%)$ for twins with no other family history of ALS (18).

Recently it has been suggested that genetic contributions to ALS may represent the inheritance of risk variants of multiple genes, acting interdependently to cause ALS (19). The hypothesis that ALS may be oligogenic implies that at least two pathogenic ALS gene variants are required to initiate disease. Several studies have shown that a subset of FALS and SALS patients carry at least one known ALS-linked gene variant in conjunction with a second potentially pathogenic variant and offer support for the oligogenic concept of ALS genetics, but these data have been questioned on the basis that the second gene variant may represent a benign variant, potential cohort selection bias and small sample size, and further validation was recommended $(6,8)$. Regardless of the extent to which an oligogenic mechanism is proven in ALS pathogenesis, available data suggest that genetic risk for ALS probably represents combined effects of multiple genes that establish a person's overall genetic susceptibility, acting in conjunction with environmental and random effects leading to disease onset $(8,12)$.

\section{Familial inheritance patterns in ALS}

Inheritance of most forms of familial ALS is autosomal dominant although autosomal recessive and X-linked dominant familial ALS also occur. Different modes of inheritance 
may be associated with the same gene depending on the specific sequence variant involved, as noted below (12). In practice there has been some agreement that ALS is considered familial if at least one first- or second-degree relative is reported to have ALS (20). However, the presentation of ALS and FTD in first degree relatives in some families, and observed co-occurrence of ALS with FTD in some ALS patients, was considered in a recently proposed algorithm for the diagnosis of familial ALS (Table 1) (14). Within that framework, a seemingly sporadic ALS patient with a family history of FTD in a first-degree relative would be considered to have possible familial ALS (14). Validity of this concept is supported by the discovery that an abnormal expansion of a hexanucleotide repeat (GGGGCC) in chromosome 9 open reading frame 72 (C9ORF72), a gene of unknown function further discussed below, is the most common gene variant linked to ALS and is also commonly associated with ALS-FTD and pure FTD (21-22). While there remains no formally agreed upon definition of familial ALS in the literature, the proposed working definition based on a history of ALS in a first degree or second degree relative, or potentially in the case of a history of FTD in a first-degree relative seems adequately supported (Table 1).

\section{Gene variants linked to ALS pathogenesis}

A growing number gene variants associated with Mendelian inheritance of ALS have been reported (Table 2). In outbred populations approximately $60-70 \%$ of FALS is accounted for by known ALS-linked genes (8). However, reports of families in which linkage to known loci has been excluded indicate further genetic heterogeneity (23-25). With some geographic variation, the C9ORF72 hexanucleotide repeat expansion accounts for approximately $40 \%$ of FALS in North America and Europe, while SOD1 variants linked to disease are found in about 12\%, transactive response DNA binding protein 43 (TARDPB) and fused in sarcoma (FUS) gene variants account for a few percent each, and other less common or rare gene variants are found in the remainder (8). As mentioned, these figures may vary depending upon the population being considered; for example, sequence variants such as the C9ORF72 hexanucleotide repeat expansion in ALS patients in Finland, and TARDBP in ALS patients in Sardinia are significantly more frequent as causes of FALS than in the US or other parts of Europe, and SODI variants are rare among ALS patients in the Netherlands $(22,26-27)$.

Although associations between the foregoing gene variants and FALS are well established each is also found infrequently in SALS patients. The possibility of incomplete information regarding the family history may be the basis for some of these observations, but documented nonpenetrance is established for the C9ORF72 repeat expansion and for some SODI, TARDBP, and FUS variants (28-33). De novo occurrence of sequence variants associated with ALS appears to be uncommon, but has been documented in a single report of a SOD1 variant, and in multiple reports on FUS variants (34-36). The main message from these observations is that absence of a family history of ALS may not rule out the presence of a gene variant associated with FALS, although the likelihood is modest, approximately $\sim 7 \%$ in the case of the C9ORF72 repeat expansion, $1-2 \%$ for $S O D 1$ variants and $\sim 1 \%$ for TARDBP, FUS, and $V C P$ variants (8). 
Four ALS causative genes linked to over 50\% of FALS patients are discussed briefly below in order based on relative frequency of association with ALS. These genes are also the most the most likely to be involved in SALS patients found to carry a recognized ALS-linked gene variant.

\section{Chromosome 9 open reading frame 72 (C9ORF72)}

A GGGGCC hexanucleotide repeat in the first intron of a gene that encodes a protein of unknown function on chromosome 9, C9ORF72, is the most common gene variant associated with FALS, found in 40\% of FALS and about 6-8\% of SALS patients, with ethnic variation as noted above (37). "C9FTD/ALS" phenotypes include classical ALS (infrequently PMA or PLS), ALS/FTD, and FTD, as well as dopa non-responsive parkinsonian and Huntington disease phenotypes (38-41). FTD or less severe frontotemporal cognitive impairment in C9FTD/ALS patients with ALS may arise with, prior to or after onset of motor signs in up to $50 \%$ of patients (42). Inheritance is autosomal dominant with incomplete penetrance; median age of onset is 58 years, ranging from the $4^{\text {th }}$ through $9^{\text {th }}$ decades (37). Genetic anticipation, the onset of C9FTD/ALSALS at earlier age in affected offspring than in affected parents, was suggested by some reports but is not confirmed $(38,43-44)$. Normal repeat length is $2-10 \mathrm{G}_{4} \mathrm{C}_{2}$ units; expansions larger than 20 units are reported with c9FTD/ALS but minimum repeat length linked to disease is not established $(21-22,44)$. Molecular pathogenesis of C9FTD/ALS may include haploinsufficiency of $C 9 O R F 72$ proteins and neurotoxicity from RNA-based gain of function mechanisms, although data increasingly support the latter as the primary component (45-46). Support for the diagnosis of C9FTD/ALS can be obtained at autopsy owing to the presence in brain of distinctive neuronal inclusions reactive for $\mathrm{p} 62$, ubiquitin and dipeptide repeat protein species bidirectionally transcribed from the repeat expansion, referred to as C9RAN proteins (47-48). These changes occur on a background of ubiqutinand TDP-43-positive inclusions in neurons and glia of affected brain regions, similar to that in sporadic ALS (49-51). DNA testing for the repeat expansion is generally based on a polymerase chain reaction (PCR) screening test which does not reliably quantitate repeat number beyond about 50 repeats (21-22). Southern blot, the 'gold-standard' for confirmation of the presence of abnormal C9ORF72 repeat expansions, is technically demanding and may not allow precise determination of repeat length in patients with relatively long repeats but should be performed if PCR screening is ambiguous regarding the presence or absence of an abnormal repeat expansion $(21,44)$. An additional issue is that repeat length varies across and within tissues and estimates of repeat length in blood may not reflect repeat length in brain (52).

\section{Superoxide dismutase 1 (SOD1)}

Sequence variants in the $\mathrm{Cu} / \mathrm{Zn}$ superoxide dismutase gene ( $S O D 1$ ) on chromosome 21q12.1, were the first causative gene variants identified in ALS (3). Native SOD1 protein catalyzes reduction of superoxide to hydrogen peroxide; molecular pathogenesis of SOD1 ALS is not established but several lines of evidence point to a toxic gain-of-function mechanism (12). Disease-linked variants are mainly point mutations and account for a approximately $12 \%$ of patients with FALS and 1-2\% of SALS, with ethnic variation in prevalence $(3,8)$. Over 160 pathogenic SODl variants are known, with significant 
geographic variation reported for some variants (12). Inheritance with all but one of these is autosomal dominant. The SOD1 D91A variant, found mainly in ALS patients in Sweden and Finland, is associated with a relatively slowly progressive motor with autosomal recessive inheritance (53). Phenotypes of SOD1 ALS include classical ALS and PMA, often with asymmetrical lower limb onset; when upper motor neuron signs are found lower motor neuron signs tend to predominate (54). Age of onset in most reported patients with SODI ALS is approximately 47 years with greater variability in disease duration than for age of onset (54-55). However, age at onset and severity may vary significantly depending upon the variant involved, and within families for some variants such as SOD1 I114T, and penetrance may be $<100 \%(30,55-57)$. Frontotemporal cognitive impairment is rare in SODI ALS (12). Pathological hallmarks of SODI ALS in post mortem brain and spinal cord include intracellular neuronal and astrocytic protein aggregates marked by ubiquinated neuronal and astrocytic inclusions reactive for SOD1 in motor and non-motor systems (54). DNA testing for $S O D 1$ variants is available through clinical laboratories to establish a genetic diagnosis of SOD1 ALS (58).

\section{Transactive response DNA binding protein 43 (TARDBP)}

Identification of TARDBP variants in ALS patients followed the discovery in 2006 that neuronal cytoplasmic inclusions immunoreactive for ubiquitin, a pathological hallmark in the large majority of cases of FALS and SALS, are also immunoreactive for TDP-43 (59). Recognition at that time that about half of patients with pathologically proven frontotemporal lobar degeneration (FTLD, the pathological basis for the clinical syndrome FTD) have similar TDP-43 immunoreactive inclusions established a pathological link between ALS and FTD, and led to the concept that ALS, ALS-FTD and FTD represent a clinical and pathological spectrum referred to as TDP-43 proteinopathies (60). Gene variants in TARDBP, which encodes the 43-kD TAR DNA-binding protein 43 (TDP-43), are found in approximately $4 \%$ of FALS and $1 \%$ of SALS, with some regional variation. $(8,29,32)$. TDP-43 regulates gene expression and RNA splicing (60). Available evidence suggests that dysregulation of gene expression, including RNA splicing, attributed to pathogenic TARDPB variants, in conjunction with a toxic gain-of-function of mutant TDP-43 protein, contribute to neurodegeneration but the causal mechanism is not established (61). More than 30 sequence variants have been associated with TARDBP ALS, most in the C-terminal glycine-rich domain; inheritance in all is autosomal dominant (60). Clinical phenotypes linked to pathogenic TARDPB variants include classical ALS and rarely Parkinson disease or FTD (62-66). Upper limb onset is reported to be more common in TARDBP ALS and survival somewhat longer than in SALS generally, but in clinical practice these differences have limited utility in identifying patients with TARDBP ALS (64). Pathology of TARDPB ALS is similar to most cases of SALS pathology, demonstrating neuronal cytoplasmic inclusions immunoreactive for TDP-43 throughout the brain, but particularly in motor cortex, spinal cord, basal ganglia and thalamus (60). DNA testing for ALS-linked TARDPB variants is available through clinical laboratories (58).

\section{Fused in sarcoma (FUS)}

Variants in the gene fused in sarcoma (FUS) are linked to autosomal dominant ALS in about $4 \%$ of FALS and $1 \%$ of SALS patients $(8,33,67-68)$. FUS appears to regulate DNA and 
RNA metabolism and be involved in RNA transcription, splicing and processing; gene sequence variants that alter these functions may contribute to neurodegeneration but the molecular pathogenesis of FUS related neurodegeneration is not fully defined (69). Pathogenic FUS variants include point mutations and other structural defects, and are notable for several reports confirming de novo mutations associated with ALS (35-36, 7073). Inheritance is autosomal dominant aside from a single family with apparent autosomal recessive inheritance (68). ALS phenotypes include adult-onset ALS, ALS/FTD, and juvenile ALS, and rarely as pure FTD (69). A single family with a FUS "ALS-plus" syndrome with ocular, autonomic and cerebellar features also has been reported (74). Disease progression in juvenile FUS ALS tends to be rapid, without development of FTD (75-76). Pathological hallmarks of adult-onset FUS ALS in post mortem brain and spinal cord include abnormal protein aggregates immunoreactive for FUS, mainly in the cytoplasm but also in nuclei of neurons and glia $(33,77)$. Juvenile onset FUS ALS demonstrates distinctive pathology marked by neuronal basophilic inclusions immunoreactive for FUS protein; similar pathology has been reported in adult-onset FUS FTD but rarely for FUS ALS (75-76, 78-79). DNA testing to identify FUS variants is available through clinical laboratories (58).

\section{Other ALS risk genes and insights from ALS genetics on the pathogenesis of ALS}

The list of additional genes with sequence variants associated with ALS and related phenotypes continues to grow, aided by technological advances in large scale genetic screening in FALS and SALS patients, particularly whole exome analysis in recent studies (Table 2) (6-7). Although most of these genes contribute to a relatively small proportion of FALS and/or SALS, they and more common FALS genes have offered insights regarding ALS pathogenesis. Shared functional characteristics of protein products of these genes and related post mortem pathology have directed attention to specific molecular pathways in ALS pathogenesis, and in turn has supported development of molecular models of ALS pathogenesis and development of new therapeutic strategies $(61,80-81)$.

Pathogenic TARDPB and FUS variants found in ALS and recognized functional and structural similarities between TDP-43 and FUS protein focused attention on potentially disordered RNA processing and splicing in ALS generally $(33,62-63,68)$. Relevance of defective RNA processing to ALS pathogenesis was more recently reinforced by the discovery of pathogenic MATR3 and nhRNPAl variants in ALS patients, as both genes appear to have a role in normal RNA processing (82-83). Although the specific function of C9ORF72 protein is not established, molecular and pathological evidence in C9FTD/ALS offers further support for the concept that disordered RNA processing contributes to ALS (45-46, 84-87).

The discovery that mutations in the ubiquilin-2 gene (UBQLN2, which encodes ubiquilin-2) are a rare cause X-linked dominant ALS and ALS/FTD in males, with reduced penetrance in females, reinforced the concept that disruption of protein degradation pathways may be important in ALS (88). Abnormal protein aggregates in affected brain regions in the majority of cases of FALS and SALS patients are immunoreactive at post mortem for ubiquilin-2, and functional analysis suggests that $U B Q L N 2$ mutations resulting in ALS and 
ALS/FTD are pathogenic owing to disruption of autophagic protein degradation $(81,88)$. Relevance of autophagy in ALS is further supported by associations between sequence variants in the genes encoding valosin containing protein $(V C P)$, optineurin $(O P T N)$ and TANK-Binding Kinase 1 (TBK1) in ALS (89-92). Protein products of these genes are involved in normal protein autophagy (89).

Genes pathogenically associated with ALS and FTD have also been linked to conditions involving other organ systems such as bone and muscle, giving rise to the designation "multisystem proteinopathy" as a group of genetic disorders demonstrating a wide phenotypic spectrum. In addition to VCP and OPTN, sequestosome 1/P62 (SQSTM1/p62), heterogeneous ribonucleoprotein $\mathrm{A} 2 \mathrm{~B} 1$ and $\mathrm{A} 1$ (HNRNPA2B1 and HNRNPA1) are genes in this category that have been linked to Paget disease of bone, inclusion body myopathy and ALS $(83,91,93)$. Disease-linked variants in these genes are uncommon in ALS but they have implicated toxic conformational changes in RNA-binding proteins with prion-like domains, such as TDP-43 and FUS, in neurodegeneration $(83,94)$.

\section{ALS-susceptibility genes associated with lower risk and potential disease modifying genes}

Beyond genes noted above, an expanding number of additional genes has been implicated in the pathogenesis of ALS, based on varied levels of supporting data, and in some cases uncertainty whether reported variants represent modifiers of clinical disease rather than direct causative factors (Table 3) $(4,6-7)$. These variants tend to be uncommon, with limited data supporting linkage with ALS; more detailed discussion is beyond the scope of this review but further information is available in recent reviews (4, 6-7). Further studies are needed to clarify the level of ALS risk associated with these genes and, in some cases confirm that the reported variant is associated with ALS rather than being a benign variant (6).

\section{Epigenetics of ALS}

Epigenetic factors may influence gene expression and disease states through dynamic cellular and physiological processes that activate and deactivate parts of the genome. DNA methylation is a well studied example shown to be involved in neurodegeneration, and could potentially play a role in phenotypic expression of FALS as well as SALS(95). Genomic DNA methylation patterns in ALS examined for alterations that could represent diseasespecific epigenetic alterations in ALS have suggested that such changes may influence gene expression, but this requires confirmation(96-97). More recent studies focusing on ALS associated with the C9ORF72 repeat expansion offer evidence that in this form of FALS histone methylation appears reduce expression of the mutant allele, and DNA methylation may be associated with less severe clinical phenotype in the form of longer survival and reduced mutation-specific pathology in affected brain regions (98-100). More studies are needed to confirm these results and investigate the potential role of epigenetic factors in other forms of FALS and in SALS. Analysis of epigenetic factors could refine genetic testing in ALS if detection and interpretation of epigenetic characteristics becomes a routine component of a patient's genetic risk profile. 


\section{ALS gene testing in clinical practice}

\section{Clinical Vignette}

A 59-year-old woman with a confirmed diagnosis of ALS has mild bulbar features but is mainly disabled by upper limb and less pronounced lower extremity weakness. Symptoms began 14 months earlier and upper and lower motor neuron signs are now present. There is mild pseudobulbar affect but no features suggestive of neuropsychiatric dysfunction; mild depression responded well to antidepressant medication. The patient questions whether her children are at risk for ALS.

There is no known family history of ALS. Her father died at 76 of a myocardial infarction with no history of neurological disorders. Her mother died of complications of dementia at age 63, characterized as "Alzheimer disease" with a clinical course of approximately 4 years, becoming mute and bedridden toward the end of her disease course with significant weight loss. The patient's only sibling is an older brother who is well. A maternal aunt developed dementia and died at approximately age 70 but no details otherwise are available; the aunt had a son thought to be alive but the patient has no information otherwise. The maternal grandparents are believed to have lived past age 70 without neurological problems.

The family history illustrates issues that can arise in evaluating the possibility that ALS in a given patient may be associated with an ALS risk gene. The family history is said to be negative with regard to ALS, but the dementia in the patient's mother had a shorter clinical course than is typical for Alzheimer disease, raising the possibility that the patient's mother may actually have had frontotemporal dementia, perhaps even accompanied by undiagnosed motor neuron disease. Dementia in the maternal aunt could reflect a familial predisposition to dementia, but limited information prevents meaningful conclusions. Family history may be clarified by review of family medical records or autopsy reports, but these may be unavailable.

If no further family history becomes available a case can be made to discuss with the patient the possibility that her disorder could be associated with a C9ORF72 repeat expansion, particularly given that frontotemporal dementia is recognized phenotype of the C9ORF72 repeat expansion. Dementia is also reported in association with other ALS linked genes including FUS and TDP-43, although these are less common. Dementia linked to SODI variants, the second most common ALS linked gene after C9ORF72, is rare. Confirmation of frontotemporal dementia in the patient's mother or the aunt would meet criteria for possible FALS according to criteria suggested by Byrne et al. (Table 1). A more common situation is the question of whether to offer DNA testing if further investigation suggests that neither the patient's mother nor the aunt are likely to have had FTD in the patient thought to have SALS.

\section{Considerations in the clinical application of DNA testing in ALS}

A challenge for the clinician upon establishing that a patient has ALS is the question of whether to offer the patient DNA testing to investigate the possibility that the patient carries an ALS-linked gene variant. While confirmation that the patient carries a sequence variant associated with ALS offers no proven gene-specific treatment options, research in this area 
may provide the patient with options for participation in future research trials involving gene targeted therapy. Anti-sense oligonucleotide and small molecule therapy has undergone early stage testing and similar experimental treatment approaches are anticipated to become available in human studies in coming years $(86,101-104)$.

Clinical features of ALS in general do not provide a reliable basis for separating of FALS from SALS in individual patients given the extent of phenotypic overlap(12). Clinical characteristics that may offer some insight as to the potential for involvement of one or another specific genes in FALS are discussed above. Family history provides critical information when available, and criteria noted in Table 1 offer a reasonable basis for clinical decision making, recognizing that fully validated criteria are not available $(14,20)$. In a patient lacking a family history of ALS the relevance of a family history of dementia in a first- or second-degree relative may be uncertain, as genetic risk applies primarily for FTD and it may be difficult to specifically confirm whether or not the cognitive disorder in the relative in question was FTD as opposed to dementia on some other basis(14). A further confound is that an amnestic syndrome diagnosable as Alzheimer disease is reported infrequently in patients with a C9ORF72 repeat expansion(105).

The foregoing discussion regarding DNA testing refers to patients with suspected FALS, but in view of data suggesting that approximately $10 \%$ of SALS patients may carry a major ALS susceptibility gene variant, there are grounds to make people with SALS aware of this possibility in order to allow the patient to make an informed decision regarding DNA testing(8). Although there may be exceptions depending upon the experience and training of the clinician, in most situations ALS patients seeking further information regarding the rationale for DNA testing and review of test results should be referred to a genetic counselor (106).

An additional issue once the decision to order DNA testing has been made is which test or tests to order. Clinical tests for ALS-linked genes are available, including C9ORF72, SOD1, FUS and TARDBP, variants of which are found in over 50\% of FALS patients (8). Although DNA tests can involve screening for several genes ordered as a group, a case can be made to consider sequential testing based on published frequency data for individual genes, in which case the C9ORF72 repeat expansion is most frequent, followed by SOD1 and then FUS and $T A R D P B$ variants. Clinical DNA test options are anticipated to increase as new ALS genes are identified. Further, as the cost of whole exome and whole genome testing declines it is likely that these methods may supplant test panels composed of a limited number of diseaselinked genes. The likelihood that genetic susceptibility to ALS is polygenic and increasing knowledge of gene variants that modify clinical phenotype will also motivate the use of next-generation screening techniques, in order to support more efficient and cost effective evaluation of the genetic risk profile of individual patients.

\section{Conclusions}

Although genetic mechanisms in ALS pathogenesis appear to play a major role in the development of ALS in a minority of patients, studies suggest that genetic factors at some level are important components of disease risk in the majority of ALS patients (8). However, 
identification of gene variants associated with ALS, regardless of the prevalence or magnitude of associated risk, has informed concepts of the pathogenesis of ALS, aided the identification of therapeutic targets, facilitated research to develop new ALS biomarkers, and supported the establishment of clinical diagnostic tests for ALS-linked genes. It has been suggested that a deeper understanding of the genetic landscape of ALS is key to recognition of environmental risk factors in ALS given the likelihood that sensitivity to environmental risks is influenced by a person's genetic background (107).

New treatment strategies aimed at blocking expression of ALS gene mutations have successfully completed early phase safety testing in the case SODI anti-sense oligonucleotide therapy, and efforts are underway to introduce small molecule and gene therapy targeting expression of the C9ORF72 repeat expansion (86, 102-104). Results of studies applying increasingly powerful next generation sequencing methodology to the discovery of new ALS risk genes, and work to identify and characterize epigenetic factors contributing to ALS pathogenesis are anticipated. These efforts are likely to contribute significantly to ALS therapy development and continue to move ALS into the realm of individualized medicine.

\section{References}

1. Kurland LT, Mulder DW. Epidemiologic investigations of amyotrophic lateral sclerosis 2. Familial aggregations indicative of dominant inheritance. I. Neurology. 1955 Mar; 5(3):182-96. [PubMed: 14356347]

2. Kurland LT, Mulder DW. Epidemiologic investigations of amyotrophic lateral sclerosis 2. Familial aggregations indicative of dominant inheritance. II. Neurology. 1955 Apr; 5(4):249-68. [PubMed: 14370376]

3. Rosen DR, Siddique T, Patterson D, Figlewicz DA, Sapp P, Hentati A, et al. Mutations in Cu/Zn superoxide dismutase gene are associated with familial amyotrophic lateral sclerosis. Nature. 1993 Mar 4; 362(6415):59-62. [PubMed: 8446170]

4. Su XW, Broach JR, Connor JR, Gerhard GS, Simmons Z. Genetic heterogeneity of amyotrophic lateral sclerosis: implications for clinical practice and research. Muscle \& nerve. 2014 Jun; 49(6): 786-803. [Review]. [PubMed: 24488689]

5. den Dunnen JT, Antonarakis SE. Mutation nomenclature extensions and suggestions to describe complex mutations: a discussion. Human mutation. 2000; 15(1):7-12. [PubMed: 10612815]

6. Leblond CS, Kaneb HM, Dion PA, Rouleau GA. Dissection of genetic factors associated with amyotrophic lateral sclerosis. Experimental neurology. 2014 Apr 26. [Review].

7. Marangi G, Traynor BJ. Genetic causes of amyotrophic lateral sclerosis: New genetic analysis methodologies entailing new opportunities and challenges. Brain research. 2014 Oct 12.

8. Renton AE, Chio A, Traynor BJ. State of play in amyotrophic lateral sclerosis genetics. Nature neuroscience. 2014 Jan; 17(1):17-23. [PubMed: 24369373]

9. Kenna KP, McLaughlin RL, Byrne S, Elamin M, Heverin M, Kenny EM, et al. Delineating the genetic heterogeneity of ALS using targeted high-throughput sequencing. Journal of medical genetics. 2013 Nov; 50(11):776-83. [Research Support, Non-U.S. Gov't]. [PubMed: 23881933]

10. Abrahams S, Leigh PN, Goldstein LH. Cognitive change in ALS: a prospective study. Neurology. 2005 Apr 12; 64(7):1222-6. [PubMed: 15824350]

11. Bennion Callister J, Pickering-Brown SM. Pathogenesis/genetics of frontotemporal dementia and how it relates to ALS. Experimental neurology. 2014 Jun 8. [Review].

12. Andersen PM, Al-Chalabi A. Clinical genetics of amyotrophic lateral sclerosis: what do we really know? Nat Rev Neurol. 2011 Nov; 7(11):603-15. [PubMed: 21989245]

13. Harms MB, Baloh RH. Clinical neurogenetics: amyotrophic lateral sclerosis. Neurol Clin. 2013 Nov; 31(4):929-50. [PubMed: 24176417] 
14. Byrne S, Bede P, Elamin M, Kenna K, Lynch C, McLaughlin R, et al. Proposed criteria for familial amyotrophic lateral sclerosis. Amyotroph Lateral Scler. 2011 May; 12(3):157-9. [PubMed: 21208036]

15. Fang F, Kamel F, Lichtenstein P, Bellocco R, Sparen P, Sandler DP, et al. Familial aggregation of amyotrophic lateral sclerosis. Ann Neurol. 2009 Jul; 66(1):94-9. [PubMed: 19670447]

16. Hanby MF, Scott KM, Scotton W, Wijesekera L, Mole T, Ellis CE, et al. The risk to relatives of patients with sporadic amyotrophic lateral sclerosis. Brain. $2011 \mathrm{Dec} ; 134(\mathrm{Pt} 12): 3454-7$. [PubMed: 21933809]

17. Wingo TS, Cutler DJ, Yarab N, Kelly CM, Glass JD. The heritability of amyotrophic lateral sclerosis in a clinically ascertained United States research registry. PLoS ONE. 2011; 6(11):e27985. [Research Support, U.S. Gov't, Non-P.H.S.]. [PubMed: 22132186]

18. Al-Chalabi A, Fang F, Hanby MF, Leigh PN, Shaw CE, Ye W, et al. An estimate of amyotrophic lateral sclerosis heritability using twin data. Journal of neurology, neurosurgery, and psychiatry. 2010 Dec; 81(12):1324-6. [Meta-Analysis Research Support, Non-U.S. Gov't].

19. van Blitterswijk M, van Es MA, Hennekam EA, Dooijes D, van Rheenen W, Medic J, et al. Evidence for an oligogenic basis of amyotrophic lateral sclerosis. Human molecular genetics. 2012 Sep 1; 21(17):3776-84. [PubMed: 22645277]

20. Byrne S, Elamin M, Bede P, Hardiman O. Absence of consensus in diagnostic criteria for familial neurodegenerative diseases. Journal of neurology, neurosurgery, and psychiatry. 2012 Apr; 83(4): $365-7$.

21. Dejesus-Hernandez M, Mackenzie IR, Boeve BF, Boxer AL, Baker M, Rutherford NJ, et al. Expanded GGGGCC Hexanucleotide Repeat in Noncoding Region of C9ORF72 Causes Chromosome 9p-Linked FTD and ALS. Neuron. 2011 Oct 20; 72(2):245-56. [PubMed: 21944778]

22. Renton AE, Majounie E, Waite A, Simon-Sanchez J, Rollinson S, Gibbs JR, et al. A Hexanucleotide Repeat Expansion in C9ORF72 Is the Cause of Chromosome 9p21-Linked ALSFTD. Neuron. 2011 Oct 20; 72(2):257-68. [PubMed: 21944779]

23. Hand CK, Khoris J, Salachas F, Gros-Louis F, Lopes AA, Mayeux-Portas V, et al. A novel locus for familial amyotrophic lateral sclerosis, on chromosome 18q. Am J Hum Genet. 2002 Jan; 70(1): 251-6. [PubMed: 11706389]

24. Hosler BA, Siddique T, Sapp PC, Sailor W, Huang MC, Hossain A, et al. Linkage of familial amyotrophic lateral sclerosis with frontotemporal dementia to chromosome 9q21-q22. Jama. 2000 Oct 4; 284(13):1664-9. [PubMed: 11015796]

25. Sapp PC, Hosler BA, McKenna-Yasek D, Chin W, Gann A, Genise H, et al. Identification of two novel loci for dominantly inherited familial amyotrophic lateral sclerosis. Am J Hum Genet. 2003 Aug; 73(2):397-403. [PubMed: 12858291]

26. Borghero G, Pugliatti M, Marrosu F, Marrosu MG, Murru MR, Floris G, et al. Genetic architecture of ALS in Sardinia. Neurobiology of aging. 2014 Dec; 35(12):2882 e7-e12. [PubMed: 25123918]

27. van Es MA, Dahlberg C, Birve A, Veldink JH, van den Berg LH, Andersen PM. Large-scale SOD1 mutation screening provides evidence for genetic heterogeneity in amyotrophic lateral sclerosis. Journal of neurology, neurosurgery, and psychiatry. 2010 May; 81(5):562-6.

28. Gamez J, Caponnetto C, Ferrera L, Syriani E, Marini V, Morales M, et al. I112M SOD1 mutation causes ALS with rapid progression and reduced penetrance in four Mediterranean families. Amyotroph Lateral Scler. 2011 Jan; 12(1):70-5. [PubMed: 20515426]

29. Kabashi E, Valdmanis PN, Dion P, Spiegelman D, McConkey BJ, Vande Velde C, et al. TARDBP mutations in individuals with sporadic and familial amyotrophic lateral sclerosis. Nat Genet. 2008 May; 40(5):572-4. [PubMed: 18372902]

30. Lopate G, Baloh RH, Al-Lozi MT, Miller TM, Fernandes Filho JA, Ni O, et al. Familial ALS with extreme phenotypic variability due to the I113T SOD1 mutation. Amyotroph Lateral Scler. 2010; 11(1-2):232-6. [PubMed: 20184521]

31. Robberecht W, Aguirre T, Van den Bosch L, Tilkin P, Cassiman JJ, Matthijs G. D90A heterozygosity in the SOD1 gene is associated with familial and apparently sporadic amyotrophic lateral sclerosis. Neurology. 1996 Nov; 47(5):1336-9. [PubMed: 8909456] 
32. Sreedharan J, Blair IP, Tripathi VB, Hu X, Vance C, Rogelj B, et al. TDP-43 mutations in familial and sporadic amyotrophic lateral sclerosis. Science (New York, NY). 2008 Mar 21; 319(5870): 1668-72.

33. Vance C, Rogelj B, Hortobagyi T, De Vos KJ, Nishimura AL, Sreedharan J, et al. Mutations in FUS, an RNA processing protein, cause familial amyotrophic lateral sclerosis type 6 . Science (New York, NY. 2009 Feb 27; 323(5918):1208-11.

34. Alexander MD, Traynor BJ, Miller N, Corr B, Frost E, McQuaid S, et al. "True" sporadic ALS associated with a novel SOD-1 mutation. Ann Neurol. 2002 Nov; 52(5):680-3. [PubMed: 12402272]

35. Chio A, Calvo A, Moglia C, Ossola I, Brunetti M, Sbaiz L, et al. A de novo missense mutation of the FUS gene in a "true" sporadic ALS case. Neurobiology of aging. 2010 Jul 1.

36. Dejesus-Hernandez M, Kocerha J, Finch N, Crook R, Baker M, Desaro P, et al. De novo truncating FUS gene mutation as a cause of sporadic amyotrophic lateral sclerosis. Human mutation. 2010 Mar 15.

37. Majounie E, Renton AE, Mok K, Dopper EG, Waite A, Rollinson S, et al. Frequency of the C9orf72 hexanucleotide repeat expansion in patients with amyotrophic lateral sclerosis and frontotemporal dementia: a cross-sectional study. Lancet neurology. 2012 Apr; 11(4):323-30. [PubMed: 22406228]

38. Boeve BF, Boylan KB, Graff-Radford NR, Dejesus-Hernandez M, Knopman DS, Pedraza O, et al. Characterization of frontotemporal dementia and/or amyotrophic lateral sclerosis associated with the GGGGCC repeat expansion in C9ORF72. Brain. 2012 Mar; 135(Pt 3):765-83. [PubMed: 22366793]

39. Hensman Moss DJ, Poulter M, Beck J, Hehir J, Polke JM, Campbell T, et al. C9orf72 expansions are the most common genetic cause of Huntington disease phenocopies. Neurology. 2014 Jan 28; 82(4):292-9. [PubMed: 24363131]

40. O'Dowd S, Curtin D, Waite AJ, Roberts K, Pender N, Reid V, et al. C9ORF72 expansion in amyotrophic lateral sclerosis/frontotemporal dementia also causes parkinsonism. Mov Disord. 2012 Jul; 27(8):1072-4. [PubMed: 22807188]

41. van Rheenen W, van Blitterswijk M, Huisman MH, Vlam L, van Doormaal PT, Seelen M, et al. Hexanucleotide repeat expansions in C9ORF72 in the spectrum of motor neuron diseases. Neurology. 2012 Aug 28; 79(9):878-82. [PubMed: 22843265]

42. Byrne S, Elamin M, Bede P, Shatunov A, Walsh C, Corr B, et al. Cognitive and clinical characteristics of patients with amyotrophic lateral sclerosis carrying a $\mathrm{C} 9$ orf 72 repeat expansion: a population-based cohort study. Lancet neurology. 2012 Mar; 11(3):232-40. [PubMed: 22305801]

43. Chio A, Borghero G, Restagno G, Mora G, Drepper C, Traynor BJ, et al. Clinical characteristics of patients with familial amyotrophic lateral sclerosis carrying the pathogenic GGGGCC hexanucleotide repeat expansion of C9ORF72. Brain. 2012 Mar; 135(Pt 3):784-93. [PubMed: 22366794]

44. Rohrer JD, Isaacs AM, Mizielinska S, Mead S, Lashley T, Wray S, et al. C9orf72 expansions in frontotemporal dementia and amyotrophic lateral sclerosis. The Lancet Neurology. 2015 Mar; 14(3):291-301. [Review]. [PubMed: 25638642]

45. Gendron TF, Belzil VV, Zhang YJ, Petrucelli L. Mechanisms of toxicity in C9FTLD/ALS. Acta neuropathologica. 2014 Mar; 127(3):359-76. [PubMed: 24394885]

46. Mizielinska S, Isaacs AM. C9orf72 amyotrophic lateral sclerosis and frontotemporal dementia: gain or loss of function? Current opinion in neurology. 2014 Oct; 27(5):515-23. [PubMed: 25188012]

47. Mackenzie IR, Arzberger T, Kremmer E, Troost D, Lorenzl S, Mori K, et al. Dipeptide repeat protein pathology in C9ORF72 mutation cases: clinico-pathological correlations. Acta neuropathologica. 2013 Dec; 126(6):859-79. [Research Support, Non-U.S. Gov't]. [PubMed: 24096617]

48. Gendron TF, Bieniek KF, Zhang YJ, Jansen-West K, Ash PE, Caulfield T, et al. Antisense transcripts of the expanded C9ORF72 hexanucleotide repeat form nuclear RNA foci and undergo 
repeat-associated non-ATG translation in c9FTD/ALS. Acta neuropathologica. 2013 Dec; 126(6): 829-44. [PubMed: 24129584]

49. Brettschneider J, Del Tredici K, Toledo JB, Robinson JL, Irwin DJ, Grossman M, et al. Stages of pTDP-43 pathology in amyotrophic lateral sclerosis. Annals of neurology. $2013 \mathrm{Jul}$; 74(1):20-38. [Research Support, N.I.H., Extramural Research Support, Non-U.S. Gov't]. [PubMed: 23686809]

50. Cooper-Knock J, Hewitt C, Highley JR, Brockington A, Milano A, Man S, et al. Clinicopathological features in amyotrophic lateral sclerosis with expansions in C9ORF72. Brain. 2012 Mar; 135(Pt 3):751-64. [PubMed: 22366792]

51. Murray ME, Dejesus-Hernandez M, Rutherford NJ, Baker M, Duara R, Graff-Radford NR, et al. Clinical and neuropathologic heterogeneity of c9FTD/ALS associated with hexanucleotide repeat expansion in C9ORF72. Acta neuropathologica. 2011 Nov 15.

52. van Blitterswijk M, DeJesus-Hernandez M, Niemantsverdriet E, Murray ME, Heckman MG, Diehl $\mathrm{NN}$, et al. Association between repeat sizes and clinical and pathological characteristics in carriers of C9ORF72 repeat expansions (Xpansize-72): a cross-sectional cohort study. Lancet neurology. 2013 Oct; 12(10):978-88. [PubMed: 24011653]

53. Andersen PM, Forsgren L, Binzer M, Nilsson P, Ala-Hurula V, Keranen ML, et al. Autosomal recessive adult-onset amyotrophic lateral sclerosis associated with homozygosity for Asp90Ala $\mathrm{CuZn}$-superoxide dismutase mutation A clinical and genealogical study of 36 patients. Brain. 1996 Aug; 119( Pt 4):1153-72. [PubMed: 8813280]

54. Andersen PM. Amyotrophic lateral sclerosis associated with mutations in the $\mathrm{CuZn}$ superoxide dismutase gene. Current neurology and neuroscience reports. 2006 Jan; 6(1):37-46. [PubMed: 16469270]

55. Cudkowicz ME, McKenna-Yasek D, Sapp PE, Chin W, Geller B, Hayden DL, et al. Epidemiology of mutations in superoxide dismutase in amyotrophic lateral sclerosis. Ann Neurol. 1997 Feb; 41(2):210-21. [PubMed: 9029070]

56. Cudkowicz ME, McKenna-Yasek D, Chen C, Hedley-Whyte ET, Brown RH Jr. Limited corticospinal tract involvement in amyotrophic lateral sclerosis subjects with the A4V mutation in the copper/zinc superoxide dismutase gene. Ann Neurol. 1998 Jun; 43(6):703-10. [PubMed: 9629839]

57. Felbecker A, Camu W, Valdmanis PN, Sperfeld AD, Waibel S, Steinbach P, et al. Four familial ALS pedigrees discordant for two SOD1 mutations: are all SOD1 mutations pathogenic? Journal of neurology, neurosurgery, and psychiatry. 2010 May; 81(5):572-7.

58. Gene_Tests. Web site with information on facilities that offer DNA testing for ALS linked gene variants. Available from: https://www.genetests.org/

59. Neumann M, Sampathu DM, Kwong LK, Truax AC, Micsenyi MC, Chou TT, et al. Ubiquitinated TDP-43 in frontotemporal lobar degeneration and amyotrophic lateral sclerosis. Science (New York, NY). 2006 Oct 6; 314(5796):130-3.

60. Chen-Plotkin AS, Lee VM, Trojanowski JQ. TAR DNA-binding protein 43 in neurodegenerative disease. Nat Rev Neurol. 2010 Apr; 6(4):211-20. [PubMed: 20234357]

61. Scotter EL, Chen HJ, Shaw CE. TDP-43 Proteinopathy and ALS: Insights into Disease Mechanisms and Therapeutic Targets. Neurotherapeutics. 2015 Feb 5.

62. Benajiba L, Le Ber I, Camuzat A, Lacoste M, Thomas-Anterion C, Couratier P, et al. TARDBP mutations in motoneuron disease with frontotemporal lobar degeneration. Ann Neurol. 2009 Apr; 65(4):470-3. [PubMed: 19350673]

63. Borroni B, Bonvicini C, Alberici A, Buratti E, Agosti C, Archetti S, et al. Mutation within TARDBP leads to frontotemporal dementia without motor neuron disease. Human mutation. 2009 Nov; 30(11):E974-83. [PubMed: 19655382]

64. Corcia P, Valdmanis P, Millecamps S, Lionnet C, Blasco H, Mouzat K, et al. Phenotype and genotype analysis in amyotrophic lateral sclerosis with TARDBP gene mutations. Neurology. 2012 May 8; 78(19):1519-26. [PubMed: 22539580]

65. Quadri M, Cossu G, Saddi V, Simons EJ, Murgia D, Melis M, et al. Broadening the phenotype of TARDBP mutations: the TARDBP Ala382Thr mutation and Parkinson's disease in Sardinia. Neurogenetics. 2011 Aug; 12(3):203-9. [PubMed: 21667065] 
66. Rayaprolu S, Fujioka S, Traynor S, Soto-Ortolaza AI, Petrucelli L, Dickson DW, et al. TARDBP mutations in Parkinson's disease. Parkinsonism Relat Disord. 2012 Dec 8.

67. Hewitt C, Kirby J, Highley JR, Hartley JA, Hibberd R, Hollinger HC, et al. Novel FUS/TLS mutations and pathology in familial and sporadic amyotrophic lateral sclerosis. Arch Neurol. 2010 Apr; 67(4):455-61. [PubMed: 20385912]

68. Kwiatkowski TJ Jr, Bosco DA, Leclerc AL, Tamrazian E, Vanderburg CR, Russ C, et al. Mutations in the FUS/TLS gene on chromosome 16 cause familial amyotrophic lateral sclerosis. Science (New York, NY). 2009 Feb 27; 323(5918):1205-8.

69. Deng H, Gao K, Jankovic J. The role of FUS gene variants in neurodegenerative diseases. Nat Rev Neurol. 2014 Jun; 10(6):337-48. [PubMed: 24840975]

70. Calvo A, Moglia C, Canosa A, Brunetti M, Barberis M, Traynor BJ, et al. De novo nonsense mutation of the FUS gene in an apparently familial amyotrophic lateral sclerosis case. Neurobiology of aging. 2014 Jun; 35(6):1513 e7-11. [PubMed: 24439481]

71. Kim YE, Oh KW, Kwon MJ, Choi WJ, Oh SI, Ki CS, et al. De novo FUS mutations in 2 Korean patients with sporadic amyotrophic lateral sclerosis. Neurobiology of aging. 2015 Mar; 36(3):1604 e17-9. [PubMed: 25457557]

72. Robertson J, Bilbao J, Zinman L, Hazrati LN, Tokuhiro S, Sato C, et al. A novel double mutation in FUS gene causing sporadic ALS. Neurobiology of aging. 2010 Jun 17.

73. Zou ZY, Cui LY, Sun Q, Li XG, Liu MS, Xu Y, et al. De novo FUS gene mutations are associated with juvenile-onset sporadic amyotrophic lateral sclerosis in China. Neurobiology of aging. 2013 Apr; 34(4):1312 e1-8. [PubMed: 23046859]

74. Tateishi T, Hokonohara T, Yamasaki R, Miura S, Kikuchi H, Iwaki A, et al. Multiple system degeneration with basophilic inclusions in Japanese ALS patients with FUS mutation. Acta neuropathologica. 2010 Mar; 119(3):355-64. [PubMed: 19967541]

75. Baumer D, Hilton D, Paine SM, Turner MR, Lowe J, Talbot K, et al. Juvenile ALS with basophilic inclusions is a FUS proteinopathy with FUS mutations. Neurology. 2010 Aug 17; 75(7):611-8. [PubMed: 20668261]

76. Huang EJ, Zhang J, Geser F, Trojanowski JQ, Strober JB, Dickson DW, et al. Extensive FUSImmunoreactive Pathology in Juvenile Amyotrophic Lateral Sclerosis with Basophilic Inclusions. Brain Pathol. 2010 May 25.

77. Neumann M, Rademakers R, Roeber S, Baker M, Kretzschmar HA, Mackenzie IR. Frontotemporal lobar degeneration with FUS pathology. Brain. 2009 Aug 11.

78. Matsuoka T, Fujii N, Kondo A, Iwaki A, Hokonohara T, Honda H, et al. An autopsied case of sporadic adult-onset amyotrophic lateral sclerosis with FUS-positive basophilic inclusions. Neuropathology. 2010 Jun 21.

79. Munoz DG, Neumann M, Kusaka H, Yokota O, Ishihara K, Terada S, et al. FUS pathology in basophilic inclusion body disease. Acta neuropathologica. 2009 Nov; 118(5):617-27. [PubMed: 19830439]

80. Bettencourt C, Houlden H. Exome sequencing uncovers hidden pathways in familial and sporadic ALS. Nature neuroscience. 2015 Apr 28; 18(5):611-3. [PubMed: 25919956]

81. Fecto F, Siddique T. UBQLN2/P62 cellular recycling pathways in amyotrophic lateral sclerosis and frontotemporal dementia. Muscle \& nerve. 2012 Feb; 45(2):157-62. [PubMed: 22246868]

82. Johnson JO, Pioro EP, Boehringer A, Chia R, Feit H, Renton AE, et al. Mutations in the Matrin 3 gene cause familial amyotrophic lateral sclerosis. Nature neuroscience. 2014 May; 17(5):664-6. [PubMed: 24686783]

83. Kim HJ, Kim NC, Wang YD, Scarborough EA, Moore J, Diaz Z, et al. Mutations in prion-like domains in hnRNPA2B1 and hnRNPA1 cause multisystem proteinopathy and ALS. Nature. 2013 Mar 28; 495(7442):467-73. [PubMed: 23455423]

84. Cooper-Knock J, Walsh MJ, Higginbottom A, Robin Highley J, Dickman MJ, Edbauer D, et al. Sequestration of multiple RNA recognition motif-containing proteins by $\mathrm{C} 9$ orf 72 repeat expansions. Brain. 2014 May 27.

85. Donnelly CJ, Zhang PW, Pham JT, Heusler AR, Mistry NA, Vidensky S, et al. RNA toxicity from the ALS/FTD C9ORF72 expansion is mitigated by antisense intervention. Neuron. 2013 Oct 16; 80(2):415-28. [PubMed: 24139042] 
86. Lagier-Tourenne C, Baughn M, Rigo F, Sun S, Liu P, Li HR, et al. Targeted degradation of sense and antisense C9orf72 RNA foci as therapy for ALS and frontotemporal degeneration.

Proceedings of the National Academy of Sciences of the United States of America. 2013 Nov 19; 110(47):E4530-9. [PubMed: 24170860]

87. Lee YB, Chen HJ, Peres JN, Gomez-Deza J, Attig J, Stalekar M, et al. Hexanucleotide repeats in ALS/FTD form length-dependent RNA foci, sequester RNA binding proteins, and are neurotoxic. Cell Rep. 2013 Dec 12; 5(5):1178-86. [PubMed: 24290757]

88. Deng HX, Chen W, Hong ST, Boycott KM, Gorrie GH, Siddique N, et al. Mutations in UBQLN2 cause dominant X-linked juvenile and adult-onset ALS and ALS/dementia. Nature. 2011 Sep 8; 477(7363):211-5. [PubMed: 21857683]

89. Cirulli ET, Lasseigne BN, Petrovski S, Sapp PC, Dion PA, Leblond CS, et al. Exome sequencing in amyotrophic lateral sclerosis identifies risk genes and pathways. Science (New York, NY. 2015 Feb 19.

90. Freischmidt A, Wieland T, Richter B, Ruf W, Schaeffer V, Muller K, et al. Haploinsufficiency of TBK1 causes familial ALS and fronto-temporal dementia. Nature neuroscience. 2015 Mar 24.

91. Johnson JO, Mandrioli J, Benatar M, Abramzon Y, Van Deerlin VM, Trojanowski JQ, et al. Exome sequencing reveals VCP mutations as a cause of familial ALS. Neuron. 2010 Dec 9; 68(5): 857-64. [PubMed: 21145000]

92. Murayama S. Clinical and pathological characteristics of FUS/TLS-associated amyotrophic lateral sclerosis (ALS). Rinsho shinkeigaku = Clinical neurology. 2010 Nov; 50(11):948-50. [PubMed: 21921522]

93. Benatar M, Wuu J, Fernandez C, Weihl CC, Katzen H, Steele J, et al. Motor neuron involvement in multisystem proteinopathy: implications for ALS. Neurology. 2013 May 14; 80(20):1874-80. [PubMed: 23635965]

94. Couthouis J, Hart MP, Shorter J, Dejesus-Hernandez M, Erion R, Oristano R, et al. Feature Article: A yeast functional screen predicts new candidate ALS disease genes. Proceedings of the National Academy of Sciences of the United States of America. 2011 Nov 7.

95. Martin LJ, Wong M. Aberrant regulation of DNA methylation in amyotrophic lateral sclerosis: a new target of disease mechanisms. Neurotherapeutics. 2013 Oct; 10(4):722-33. [PubMed: 23900692]

96. Figueroa-Romero C, Hur J, Bender DE, Delaney CE, Cataldo MD, Smith AL, et al. Identification of epigenetically altered genes in sporadic amyotrophic lateral sclerosis. PLoS ONE. 2012; 7(12):e52672. [PubMed: 23300739]

97. Morahan JM, Yu B, Trent RJ, Pamphlett R. A genome-wide analysis of brain DNA methylation identifies new candidate genes for sporadic amyotrophic lateral sclerosis. Amyotroph Lateral Scler. 2009 Oct-Dec;10(5-6):418-29. [PubMed: 19922134]

98. Belzil VV, Bauer PO, Prudencio M, Gendron TF, Stetler CT, Yan IK, et al. Reduced C9orf72 gene expression in c9FTD/ALS is caused by histone trimethylation, an epigenetic event detectable in blood. Acta neuropathologica. 2013 Dec; 126(6):895-905. [PubMed: 24166615]

99. Liu EY, Russ J, Wu K, Neal D, Suh E, McNally AG, et al. C9orf72 hypermethylation protects against repeat expansion-associated pathology in ALS/FTD. Acta neuropathologica. 2014 May 8.

100. Russ J, Liu EY, Wu K, Neal D, Suh E, Irwin DJ, et al. Hypermethylation of repeat expanded C9orf72 is a clinical and molecular disease modifier. Acta neuropathologica. 2015 Jan; 129(1): 39-52. [PubMed: 25388784]

101. Kalmar B, Lu CH, Greensmith L. The role of heat shock proteins in Amyotrophic Lateral Sclerosis: The therapeutic potential of Arimoclomol. Pharmacol Ther. 2014 Jan; 141(1):40-54. [PubMed: 23978556]

102. Miller TM, Pestronk A, David W, Rothstein J, Simpson E, Appel SH, et al. An antisense oligonucleotide against SOD1 delivered intrathecally for patients with SOD1 familial amyotrophic lateral sclerosis: a phase 1, randomised, first-in-man study. Lancet neurology. 2013 May; 12(5):435-42. [PubMed: 23541756]

103. Sareen D, O’Rourke JG, Meera P, Muhammad AK, Grant S, Simpkinson M, et al. Targeting RNA foci in iPSC-derived motor neurons from ALS patients with a C9ORF72 repeat expansion. Sci Transl Med. 2013 Oct 23.5(208):208ra149. 
104. Su Z, Zhang Y, Gendron TF, Bauer PO, Chew J, Yang WY, et al. Discovery of a Biomarker and Lead Small Molecules to Target r(GGGGCC)-Associated Defects in c9FTD/ALS. Neuron. 2014 Sep 3; 83(5):1043-50. [PubMed: 25132468]

105. Majounie E, Abramzon Y, Renton AE, Perry R, Bassett SS, Pletnikova O, et al. Repeat expansion in C9ORF72 in Alzheimer's disease. The New England journal of medicine. 2012 Jan 19; 366(3):283-4. [PubMed: 22216764]

106. Chio A, Battistini S, Calvo A, Caponnetto C, Conforti FL, Corbo M, et al. Genetic counselling in ALS: facts, uncertainties and clinical suggestions. Journal of neurology, neurosurgery, and psychiatry. 2014 May; 85(5):478-85.

107. Al-Chalabi A, Hardiman O. The epidemiology of ALS: a conspiracy of genes, environment and time. Nature reviews Neurology. 2013 Nov; 9(11):617-28. Research Support, Non-U.S. Gov’t Review. [PubMed: 24126629]

108. Hadano S, Hand CK, Osuga H, Yanagisawa Y, Otomo A, Devon RS, et al. A gene encoding a putative GTPase regulator is mutated in familial amyotrophic lateral sclerosis 2. Nat Genet. 2001 Oct; 29(2):166-73. [PubMed: 11586298]

109. Greenway MJ, Andersen PM, Russ C, Ennis S, Cashman S, Donaghy C, et al. ANG mutations segregate with familial and 'sporadic' amyotrophic lateral sclerosis. Nat Genet. 2006; 38(4):4113. [PubMed: 16501576]

110. van Es MA, Schelhaas HJ, van Vught PW, Ticozzi N, Andersen PM, Groen EJ, et al. Angiogenin variants in Parkinson disease and amyotrophic lateral sclerosis. Ann Neurol. 2011 Dec; 70(6): 964-73. [PubMed: 22190368]

111. Daoud H, Belzil V, Martins S, Sabbagh M, Provencher P, Lacomblez L, et al. Association of long ATXN2 CAG repeat sizes with increased risk of amyotrophic lateral sclerosis. Arch Neurol. 2011 Jun; 68(6):739-42. [PubMed: 21670397]

112. Elden AC, Kim HJ, Hart MP, Chen-Plotkin AS, Johnson BS, Fang X, et al. Ataxin-2 intermediate-length polyglutamine expansions are associated with increased risk for ALS. Nature. 2010 Aug 26; 466(7310):1069-75. [PubMed: 20740007]

113. Bannwarth S, Ait-El-Mkadem S, Chaussenot A, Genin EC, Lacas-Gervais S, Fragaki K, et al. A mitochondrial origin for frontotemporal dementia and amyotrophic lateral sclerosis through CHCHD10 involvement. Brain. 2014 Aug; 137(Pt 8):2329-45. [PubMed: 24934289]

114. Johnson JO, Glynn SM, Gibbs JR, Nalls MA, Sabatelli M, Restagno G, et al. Mutations in the CHCHD10 gene are a common cause of familial amyotrophic lateral sclerosis. Brain. 2014 Dec. 137(Pt 12):e311. [PubMed: 25261972]

115. Parkinson N, Ince PG, Smith MO, Highley R, Skibinski G, Andersen PM, et al. ALS phenotypes with mutations in CHMP2B (charged multivesicular body protein 2B). Neurology. 2006 Sep 26; 67(6):1074-7. [PubMed: 16807408]

116. Lesage S, Le Ber I, Condroyer C, Broussolle E, Gabelle A, Thobois S, et al. C9orf72 repeat expansions are a rare genetic cause of parkinsonism. Brain. $2013 \mathrm{Feb} ; 136(\mathrm{Pt}$ 2):385-91. [PubMed: 23413259]

117. Snowden JS, Rollinson S, Thompson JC, Harris JM, Stopford CL, Richardson AM, et al. Distinct clinical and pathological characteristics of frontotemporal dementia associated with C9ORF72 mutations. Brain. 2012 Mar; 135(Pt 3):693-708. [PubMed: 22300873]

118. Mitchell J, Paul P, Chen HJ, Morris A, Payling M, Falchi M, et al. Familial amyotrophic lateral sclerosis is associated with a mutation in D-amino acid oxidase. Proceedings of the National Academy of Sciences of the United States of America. 2010 Apr 20; 107(16):7556-61. [PubMed: 20368421]

119. Münch C, Rosenbohm A, Sperfeld A-D, Uttner I, Reske S, Krause BJ, et al. Heterozygous R1101K mutation of the DCTN1 gene in a family with ALS and FTD. Annals of Neurology. 2005; 58(5):777-80. [PubMed: 16240349]

120. Munch C, Sedlmeier R, Meyer T, Homberg V, Sperfeld AD, Kurt A, et al. Point mutations of the p150 subunit of dynactin (DCTN1) gene in ALS. Neurology. 2004 Aug 24; 63(4):724-6. [PubMed: 15326253] 
121. Vilarino-Guell C, Wider C, Soto-Ortolaza AI, Cobb SA, Kachergus JM, Keeling BH, et al. Characterization of DCTN1 genetic variability in neurodegeneration. Neurology. 2009 Jun 9; 72(23):2024-8. [PubMed: 19506225]

122. Chow CY, Landers JE, Bergren SK, Sapp PC, Grant AE, Jones JM, et al. Deleterious variants of FIG4, a phosphoinositide phosphatase, in patients with ALS. Am J Hum Genet. 2009 Jan; 84(1): 85-8. [PubMed: 19118816]

123. Maruyama H, Morino H, Ito H, Izumi Y, Kato H, Watanabe Y, et al. Mutations of optineurin in amyotrophic lateral sclerosis. Nature. 2010 May 13; 465(7295):223-6. [PubMed: 20428114]

124. Wu CH, Fallini C, Ticozzi N, Keagle PJ, Sapp PC, Piotrowska K, et al. Mutations in the profilin 1 gene cause familial amyotrophic lateral sclerosis. Nature. $2012 \mathrm{Jul} 15$.

125. Chen YZ, Bennett CL, Huynh HM, Blair IP, Puls I, Irobi J, et al. DNA/RNA helicase gene mutations in a form of juvenile amyotrophic lateral sclerosis (ALS4). Am J Hum Genet. 2004 Jun; 74(6):1128-35. [PubMed: 15106121]

126. Al-Saif A, Al-Mohanna F, Bohlega S. A mutation in sigma-1 receptor causes juvenile amyotrophic lateral sclerosis. Ann Neurol. 2011 Dec; 70(6):913-9. [PubMed: 21842496]

127. Belzil VV, Daoud H, Camu W, Strong MJ, Dion PA, Rouleau GA. Genetic analysis of SIGMAR1 as a cause of familial ALS with dementia. Eur J Hum Genet. 2013 Feb; 21(2):237-9. [PubMed: 22739338]

128. Fukunaga K, Shinoda Y, Tagashira $\mathrm{H}$. The role of SIGMAR1 gene mutation and mitochondrial dysfunction in amyotrophic lateral sclerosis. J Pharmacol Sci. 2015 Jan; 127(1):36-41. [PubMed: 25704016]

129. Daoud H, Zhou S, Noreau A, Sabbagh M, Belzil V, Dionne-Laporte A, et al. Exome sequencing reveals SPG11 mutations causing juvenile ALS. Neurobiology of aging. 2012 Apr; 33(4):839 e59. [PubMed: 22154821]

130. Orlacchio A, Babalini C, Borreca A, Patrono C, Massa R, Basaran S, et al. SPATACSIN mutations cause autosomal recessive juvenile amyotrophic lateral sclerosis. Brain. $2010 \mathrm{Feb}$; 133(Pt 2):591-8. [PubMed: 20110243]

131. Fecto F, Yan J, Vemula SP, Liu E, Yang Y, Chen W, et al. SQSTM1 mutations in familial and sporadic amyotrophic lateral sclerosis. Arch Neurol. 2011 Nov; 68(11):1440-6. [PubMed: 22084127]

132. Yang Y, Tang L, Zhang N, Pan L, Hadano S, Fan D. Six SQSTM1 mutations in a Chinese amyotrophic lateral sclerosis cohort. Amyotroph Lateral Scler Frontotemporal Degener. 2015 Feb.24:1-7.

133. Smith BN, Ticozzi N, Fallini C, Gkazi AS, Topp S, Kenna KP, et al. Exome-wide rare variant analysis identifies TUBA4A mutations associated with familial ALS. Neuron. 2014 Oct 22; 84(2):324-31. [PubMed: 25374358]

134. Nishimura AL, Mitne-Neto M, Silva HC, Richieri-Costa A, Middleton S, Cascio D, et al. A mutation in the vesicle-trafficking protein VAPB causes late-onset spinal muscular atrophy and amyotrophic lateral sclerosis. Am J Hum Genet. 2004 Nov; 75(5):822-31. [PubMed: 15372378]

135. Zetterberg H, Jacobsson J, Rosengren L, Blennow K, Andersen PM. Association of APOE with age at onset of sporadic amyotrophic lateral sclerosis. J Neurol Sci. 2008 Oct 15; 273(1-2):67-9. [PubMed: 18656208]

136. Droppelmann CA, Wang J, Campos-Melo D, Keller B, Volkening K, Hegele RA, et al. Detection of a novel frameshift mutation and regions with homozygosis within ARHGEF28 gene in familial amyotrophic lateral sclerosis. Amyotroph Lateral Scler Frontotemporal Degener. 2013 Sep; 14(5-6):444-51. [PubMed: 23286752]

137. Ma Y, Tang L, Chen L, Zhang B, Deng P, Wang J, et al. ARHGEF28 gene exon 6/intron 6 junction mutations in Chinese amyotrophic lateral sclerosis cohort. Amyotroph Lateral Scler Frontotemporal Degener. 2014 Jun; 15(3-4):309-11. [PubMed: 24712971]

138. Gros-Louis F, Andersen PM, Dupre N, Urushitani M, Dion P, Souchon F, et al. Chromogranin B $\mathrm{P} 413 \mathrm{~L}$ variant as risk factor and modifier of disease onset for amyotrophic lateral sclerosis. Proceedings of the National Academy of Sciences of the United States of America. 2009 Dec 22; 106(51):21777-82. [PubMed: 20007371] 
139. Sabatelli M, Eusebi F, Al-Chalabi A, Conte A, Madia F, Luigetti M, et al. Rare missense variants of neuronal nicotinic acetylcholine receptor altering receptor function are associated with sporadic amyotrophic lateral sclerosis. Human molecular genetics. 2009 Oct 15; 18(20):39974006. [PubMed: 19628475]

140. Sabatelli M, Lattante S, Conte A, Marangi G, Luigetti M, Del Grande A, et al. Replication of association of CHRNA4 rare variants with sporadic amyotrophic lateral sclerosis: the Italian multicentre study. Amyotroph Lateral Scler. 2012 Oct; 13(6):580-4. [PubMed: 22873564]

141. Lopez-Lopez A, Gamez J, Syriani E, Morales M, Salvado M, Rodriguez MJ, et al. CX3CR1 is a modifying gene of survival and progression in amyotrophic lateral sclerosis. PLoS ONE. 2014; 9(5):e96528. [PubMed: 24806473]

142. Li XG, Zhang JH, Xie MQ, Liu MS, Li BH, Zhao YH, et al. Association between DPP6 polymorphism and the risk of sporadic amyotrophic lateral sclerosis in Chinese patients. Chin Med J (Engl). 2009 Dec 20; 122(24):2989-92. [PubMed: 20137488]

143. Daoud H, Valdmanis PN, Dion PA, Rouleau GA. Analysis of DPP6 and FGGY as candidate genes for amyotrophic lateral sclerosis. Amyotroph Lateral Scler. 2010 Aug; 11(4):389-91. [PubMed: 20001489]

144. van Es MA, van Vught PW, Blauw HM, Franke L, Saris CG, Van den Bosch L, et al. Genetic variation in DPP6 is associated with susceptibility to amyotrophic lateral sclerosis. Nat Genet. 2008 Jan; 40(1):29-31. [PubMed: 18084291]

145. Blasco H, Bernard-Marissal N, Vourc'h P, Guettard YO, Sunyach C, Augereau O, et al. A rare motor neuron deleterious missense mutation in the DPYSL3 (CRMP4) gene is associated with ALS. Human mutation. 2013 Jul; 34(7):953-60. [PubMed: 23568759]

146. Simpson CL, Lemmens R, Miskiewicz K, Broom WJ, Hansen VK, van Vught PW, et al. Variants of the elongator protein 3 (ELP3) gene are associated with motor neuron degeneration. Human molecular genetics. 2009 Feb 1; 18(3):472-81. [PubMed: 18996918]

147. Van Hoecke A, Schoonaert L, Lemmens R, Timmers M, Staats KA, Laird AS, et al. EPHA4 is a disease modifier of amyotrophic lateral sclerosis in animal models and in humans. Nature medicine. 2012 Aug 26.

148. Takahashi Y, Fukuda Y, Yoshimura J, Toyoda A, Kurppa K, Moritoyo H, et al. ERBB4 mutations that disrupt the neuregulin-ErbB4 pathway cause amyotrophic lateral sclerosis type 19. Am J Hum Genet. 2013 Nov 7; 93(5):900-5. [PubMed: 24119685]

149. Al-Saif A, Bohlega S, Al-Mohanna F. Loss of ERLIN2 function leads to juvenile primary lateral sclerosis. Ann Neurol. 2012 Oct; 72(4):510-6. [PubMed: 23109145]

150. Couthouis J, Hart MP, Erion R, King OD, Diaz Z, Nakaya T, et al. Evaluating the role of the FUS/TLS-related gene EWSR1 in amyotrophic lateral sclerosis. Human molecular genetics. 2012 Jul 1; 21(13):2899-911. [PubMed: 22454397]

151. Cannon A, Fujioka S, Rutherford NJ, Ferman TJ, Broderick DF, Boylan KB, et al. Clinicopathologic variability of the GRN A9D mutation, including amyotrophic lateral sclerosis. Neurology. 2013 Apr 17.

152. Sleegers K, Brouwers N, Maurer-Stroh S, van Es MA, Van Damme P, van Vught PW, et al. Progranulin genetic variability contributes to amyotrophic lateral sclerosis. Neurology. $2008 \mathrm{Jul}$ 22; 71(4):253-9. [PubMed: 18184915]

153. Goodall EF, Greenway MJ, van Marion I, Carroll CB, Hardiman O, Morrison KE. Association of the H63D polymorphism in the hemochromatosis gene with sporadic ALS. Neurology. 2005 Sep 27; 65(6):934-7. [PubMed: 16186539]

154. He X, Lu X, Hu J, Xi J, Zhou D, Shang H, et al. H63D polymorphism in the hemochromatosis gene is associated with sporadic amyotrophic lateral sclerosis in China. Eur J Neurol. 2011 Feb; 18(2):359-61. [PubMed: 20642794]

155. van Es MA, Van Vught PW, Blauw HM, Franke L, Saris CG, Andersen PM, et al. ITPR2 as a susceptibility gene in sporadic amyotrophic lateral sclerosis: a genome-wide association study. Lancet neurology. 2007 Oct; 6(10):869-77. [PubMed: 17827064]

156. Landers JE, Melki J, Meininger V, Glass JD, van den Berg LH, van Es MA, et al. Reduced expression of the Kinesin-Associated Protein 3 (KIFAP3) gene increases survival in sporadic 
amyotrophic lateral sclerosis. Proceedings of the National Academy of Sciences of the United States of America. 2009 Jun 2; 106(22):9004-9. [PubMed: 19451621]

157. Orru S, Mascia V, Casula M, Giuressi E, Loizedda A, Carcassi C, et al. Association of monoamine oxidase B alleles with age at onset in amyotrophic lateral sclerosis. Neuromuscul Disord. 1999 Dec; 9(8):593-7. [PubMed: 10619718]

158. Fang P, Xu W, Wu C, Zhu M, Li X, Hong D. MAPT as a predisposing gene for sporadic amyotrophic lateral sclerosis in the Chinese Han population. Neural Regen Res. 2013 Nov 25; 8(33):3116-23. [PubMed: 25206632]

159. Al-Chalabi A, Andersen PM, Nilsson P, Chioza B, Andersson JL, Russ C, et al. Deletions of the heavy neurofilament subunit tail in amyotrophic lateral sclerosis. Human molecular genetics. 1999 Feb; 8(2):157-64. [PubMed: 9931323]

160. Figlewicz DA, Krizus A, Martinoli MG, Meininger V, Dib M, Rouleau GA, et al. Variants of the heavy neurofilament subunit are associated with the development of amyotrophic lateral sclerosis. Human molecular genetics. 1994 Oct; 3(10):1757-61. [PubMed: 7849698]

161. Wills AM, Cronin S, Slowik A, Kasperaviciute D, Van Es MA, Morahan JM, et al. A large-scale international meta-analysis of paraoxonase gene polymorphisms in sporadic ALS. Neurology. 2009 Jul 7; 73(1):16-24. [PubMed: 19321847]

162. Eschbach J, Schwalenstocker B, Soyal SM, Bayer H, Wiesner D, Akimoto C, et al. PGC-1alpha is a male-specific disease modifier of human and experimental amyotrophic lateral sclerosis. Human molecular genetics. 2013 Sep 1; 22(17):3477-84. [PubMed: 23669350]

163. Leung CL, He CZ, Kaufmann P, Chin SS, Naini A, Liem RK, et al. A pathogenic peripherin gene mutation in a patient with amyotrophic lateral sclerosis. Brain Pathol. 2004 Jul; 14(3):290-6. [PubMed: 15446584]

164. Corcia P, Mayeux-Portas V, Khoris J, de Toffol B, Autret A, Muh JP, et al. Abnormal SMN1 gene copy number is a susceptibility factor for amyotrophic lateral sclerosis. Ann Neurol. 2002 Feb; 51(2):243-6. [PubMed: 11835381]

165. Brugman F, Wokke JH, Scheffer H, Versteeg MH, Sistermans EA, van den Berg LH. Spastin mutations in sporadic adult-onset upper motor neuron syndromes. Ann Neurol. 2005 Dec; 58(6): 865-9. [PubMed: 16240363]

166. Meyer T, Schwan A, Dullinger JS, Brocke J, Hoffmann KT, Nolte CH, et al. Early-onset ALS with long-term survival associated with spastin gene mutation. Neurology. 2005 Jul 12; 65(1): 141-3. [PubMed: 16009903]

167. Munch C, Rolfs A, Meyer T. Heterozygous S44L missense change of the spastin gene in amyotrophic lateral sclerosis. Amyotroph Lateral Scler. 2008 Aug; 9(4):251-3. [PubMed: 18608088]

168. Chesi A, Staahl BT, Jovicic A, Couthouis J, Fasolino M, Raphael AR, et al. Exome sequencing to identify de novo mutations in sporadic ALS trios. Nature neuroscience. $2013 \mathrm{Jul}$; 16(7):851-5. [PubMed: 23708140]

169. Teyssou E, Vandenberghe N, Moigneu C, Boillee S, Couratier P, Meininger V, et al. Genetic analysis of SS18L1 in French amyotrophic lateral sclerosis. Neurobiology of aging. 2014 May; 35(5):1213 e9-e12. [PubMed: 24360741]

170. Gallagher MD, Suh E, Grossman M, Elman L, McCluskey L, Van Swieten JC, et al. TMEM106B is a genetic modifier of frontotemporal lobar degeneration with C9orf72 hexanucleotide repeat expansions. Acta neuropathologica. 2014 Mar; 127(3):407-18. [PubMed: 24442578]

171. Vass R, Ashbridge E, Geser F, Hu WT, Grossman M, Clay-Falcone D, et al. Risk genotypes at TMEM106B are associated with cognitive impairment in amyotrophic lateral sclerosis. Acta neuropathologica. 2010 Nov 23.

172. Cady J, Koval ED, Benitez BA, Zaidman C, Jockel-Balsarotti J, Allred P, et al. TREM2 variant p.R47H as a risk factor for sporadic amyotrophic lateral sclerosis. JAMA Neurol. 2014 Apr; 71(4):449-53. [PubMed: 24535663]

173. Chio A, Mora G, Restagno G, Brunetti M, Ossola I, Barberis M, et al. UNC13A influences survival in Italian amyotrophic lateral sclerosis patients: a population-based study. Neurobiology of aging. 2013 Jan; 34(1):357 e1-5. 
174. Diekstra FP, van Vught PW, van Rheenen W, Koppers M, Pasterkamp RJ, van Es MA, et al. UNC13A is a modifier of survival in amyotrophic lateral sclerosis. Neurobiology of aging. 2012 Mar; 33(3):630 e3-8. [PubMed: 22118904]

175. Lambrechts D, Poesen K, Fernandez-Santiago R, Al-Chalabi A, Del Bo R, Van Vught PW, et al. Meta-analysis of vascular endothelial growth factor variations in amyotrophic lateral sclerosis: increased susceptibility in male carriers of the -2578AA genotype. Journal of medical genetics. 2009 Dec; 46(12):840-6. [PubMed: 18413368]

176. Iida A, Takahashi A, Kubo M, Saito S, Hosono N, Ohnishi Y, et al. A functional variant in ZNF512B is associated with susceptibility to amyotrophic lateral sclerosis in Japanese. Human molecular genetics. 2011 Sep 15; 20(18):3684-92. [PubMed: 21665992]

177. Tetsuka S, Morita M, Iida A, Uehara R, Ikegawa S, Nakano I. ZNF512B gene is a prognostic factor in patients with amyotrophic lateral sclerosis. J Neurol Sci. 2013 Jan 15; 324(1-2):163-6. [PubMed: 23168171] 


\section{Key Points}

ALS is genetically heterogeneous with over 50 potential causative or disease modifying genes identified, but C9ORF72, SOD1, TARDPB and FUS presently account for $>50 \%$ of ALS-linked gene variants found in ALS patients and variants in other genes are relatively uncommon or rare.

Genetic risk for ALS probably represents combined effects of multiple genes that establish a person's overall genetic susceptibility, acting with environmental and random effects leading to disease onset.

Clinical features in general do not reliably separate familial from sporadic ALS in individual patients owing to phenotypic overlap; family history, including history of frontotemporal dementia, aids in recognizing that a patient may have familial ALS.

ALS-linked gene variants can be presently be identified in be identified in 60-70\% of patients with familial ALS, a proportion likely to grow, and a pathogenic ALS gene variant may be found in an increasing minority of patients with sporadic ALS. 


\section{Table 1}

Criteria for the diagnosis of familial amyotrophic lateral sclerosis.

\begin{tabular}{|l|l|}
\hline Classification/Level of Certainty & Family History \\
\hline \multirow{2}{*}{ Definite } & $\geq 2$ First- or second-degree relatives with ALS \\
\cline { 2 - 2 } & $\geq 1$ Relative with ALS and gene-positive cosegregation \\
\hline Probable & 1 First- or second-degree relative with ALS \\
\hline \multirow{3}{*}{ Possible } & Distant relative (third degree or beyond) with ALS \\
\cline { 2 - 2 } & Sporadic ALS patient with no family history but positive for a FALS gene \\
\cline { 2 - 2 } & $\geq 1$ First- or second-degree relative with confirmed frontotemporal dementia \\
\hline $\begin{array}{l}\text { Definitions: First-degree relatives: parents, children and siblings; second-degree relatives: grandparent, aunts/uncles. Adapted from Byrne, et al. } \\
\text { (14). }\end{array}$ \\
\hline
\end{tabular}




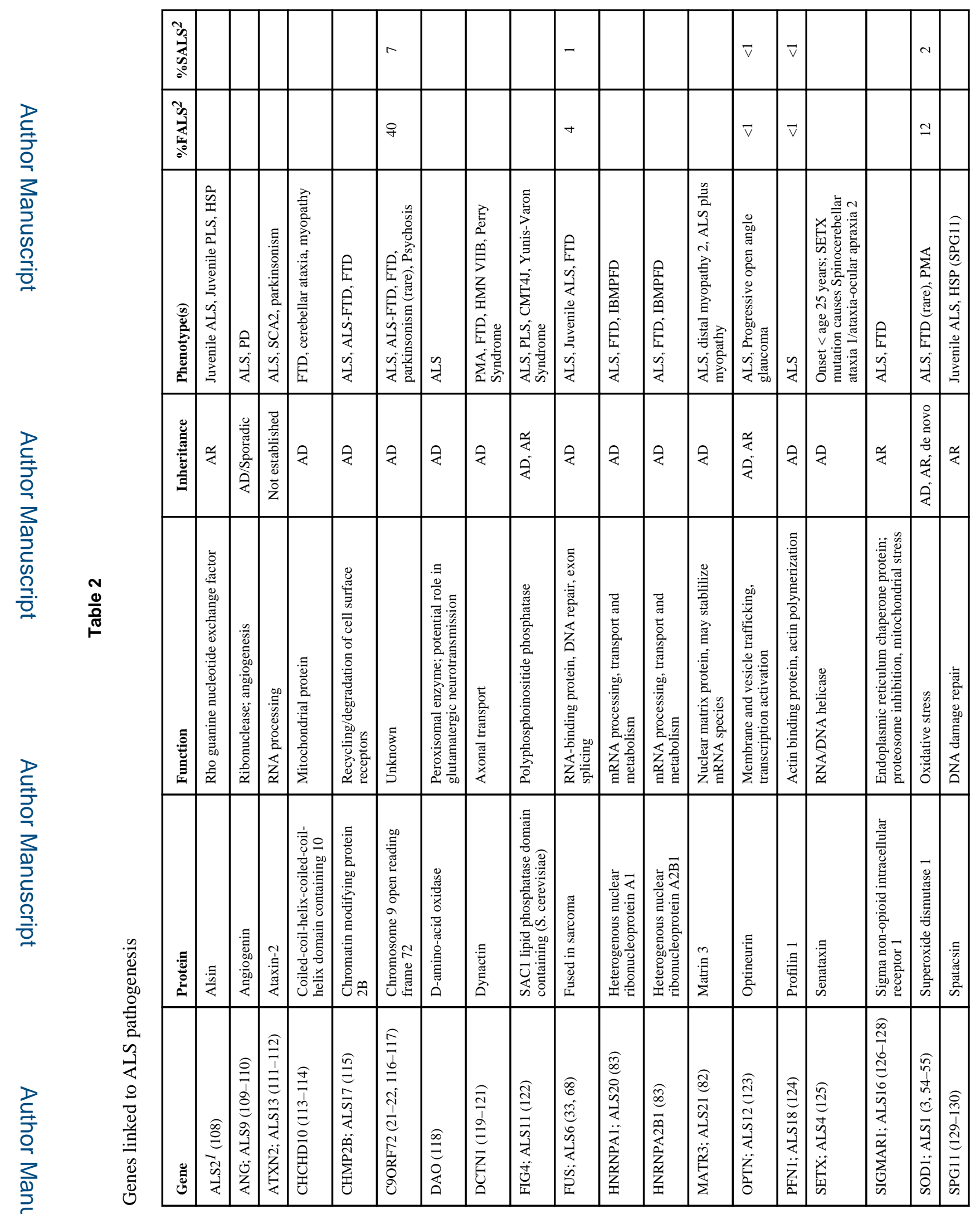

Neurol Clin. Author manuscript; available in PMC 2016 November 01. 


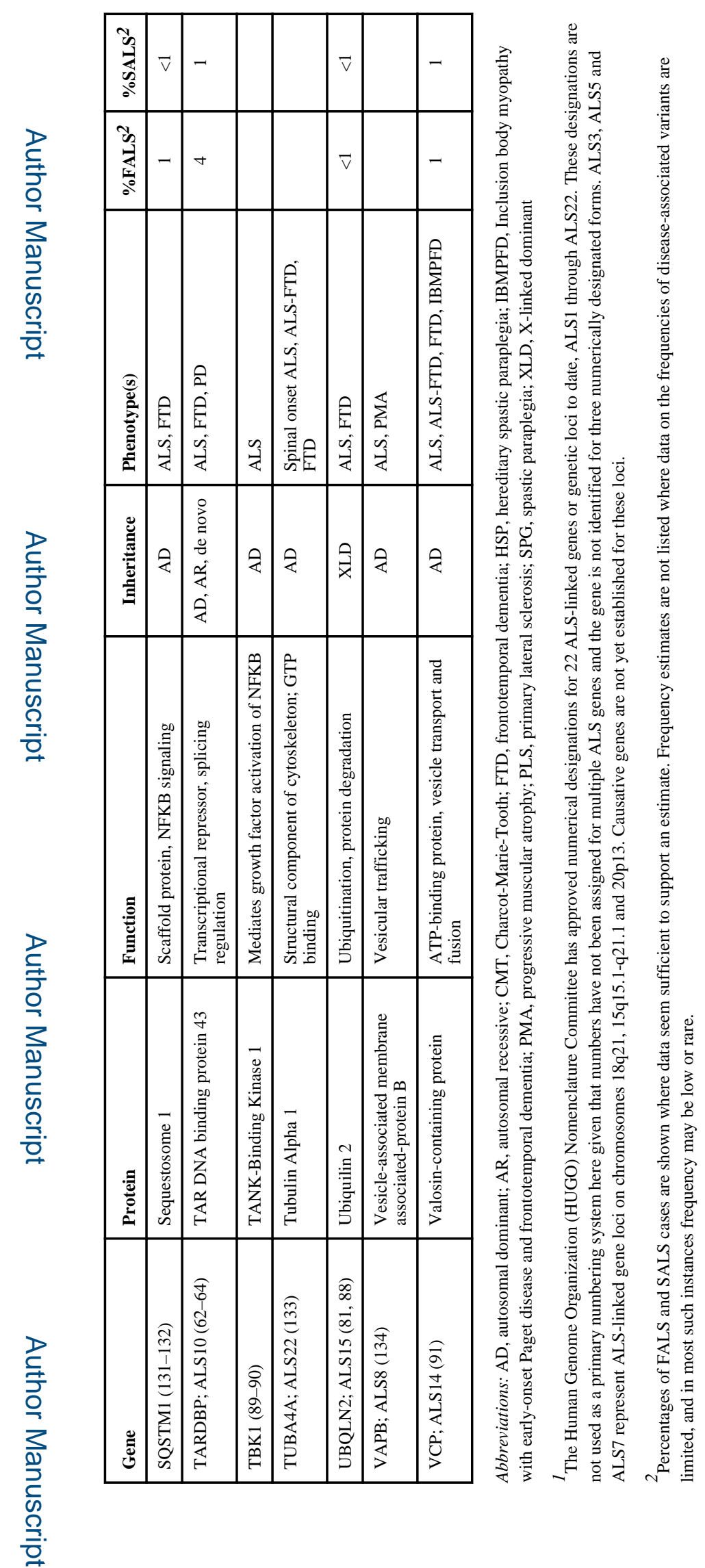

Neurol Clin. Author manuscript; available in PMC 2016 November 01. 
Table 3

Genes associated with potential causative or disease modifying effects in ALS

\begin{tabular}{|c|c|c|}
\hline Gene & Protein & Function \\
\hline APOE(135) & Apolipoprotein E & Lipoprotein metabolism, immune regulation \\
\hline ARHGEF28 (136-137) & Rho guanine nucleotide exchange factor (GEF) 28 & Regulates integrin and growth factor signaling pathways \\
\hline $\mathrm{CHGB}(138)$ & Chromogranin B & Neuroendocrine secretory granule protein \\
\hline CHRNA3 (139) & Neuronal acetylcholine receptor subunit alpha-3 & Nicotinic acetylcholine receptor subunit \\
\hline CHRNA4 (140) & Neuronal acetylcholine receptor subunit alpha-4 & Nicotinic acetylcholine receptor subunit \\
\hline CHRNB4 (139) & Neuronal acetylcholine receptor subunit beta- 4 & Nicotinic acetylcholine receptor subunit \\
\hline CX3CR1(141) & CX3C chemokine receptor 1 & Chemokine receptor \\
\hline DPP6 (142-144) & Dipeptidyl-peptidase 6 & $\begin{array}{l}\text { Alters expression/properties of voltage-gated } \mathrm{K}+ \\
\text { channels }\end{array}$ \\
\hline DPYSL3(145) & Dihydropyrimidinase-Like 3 & Class 3 semaphorin signaling, cytoskeletal remodeling \\
\hline ELP3(146) & Elongator acetyltransferase complex subunit 3 & Transcript elongation \\
\hline EPHA3 (147) & $\mathrm{EPH}$ receptor A3 & $\begin{array}{l}\text { Neighboring cell signaling, axonal segregation during } \\
\text { development }\end{array}$ \\
\hline EPHA4(147) & EPH receptor A4 & $\begin{array}{l}\text { Neighboring cell signaling, repair after nerve injury, } \\
\text { angiogenesis }\end{array}$ \\
\hline ERBB4; ALS19 (148) & $\begin{array}{l}\text { V-erb-B2 avian erythroblastic leukemia viral oncogene } \\
\text { homolog } 4\end{array}$ & $\begin{array}{l}\text { Tyrosine protein kinase involved in cell signaling; } \\
\text { potential effects on anti-apoptosis and gene expression }\end{array}$ \\
\hline ERLIN2 (149) & Endoplasmic reticulum lipid raft-associated protein 2 & $\begin{array}{l}\text { Endoplasmic reticulum-associated degradation of IP3 } \\
\text { receptors }\end{array}$ \\
\hline EWSR1 (150) & EWS RNA-binding protein 1 & $\begin{array}{l}\text { Gene expression, cell signaling, RNA processing and } \\
\text { transport }\end{array}$ \\
\hline GRN(151-152) & Progranulin & Regulation of cell growth \\
\hline FGGY(143) & FGGY carbohydrate kinase domain containing & Phosphorylation of carbohydrates \\
\hline $\operatorname{HFE}(153-154)$ & Hemochromatosis & Iron absorption \\
\hline ITPR2 (155) & Inositol 1,4,5-trisphosphate receptor & Mobilization of intracellular $\mathrm{Ca} 2+$ stores \\
\hline KIFAP3 (156) & Kinesin-associated protein 3 & Small G-protein \\
\hline $\operatorname{MAOB}(157)$ & Monoamine oxidase B & $\begin{array}{l}\text { Mitochondrial metabolism of neuroactive and vasoactive } \\
\text { amines }\end{array}$ \\
\hline MAPT(158) & Microtubule-associated protein tau & Supports microtubule assembly and stability \\
\hline $\operatorname{NEFH}(159-160)$ & Neurofilament heavy polypeptide & $\begin{array}{l}\text { Intracellular axonal and dendritic transport, axonal } \\
\text { structure }\end{array}$ \\
\hline PON1, 2,3(161) & Paraoxonase & Hydrolysis of organophosphates \\
\hline PPARGC1A(162) & $\begin{array}{l}\text { Peroxisome proliferator-activated receptor gamma, } \\
\text { coactivator } 1 \text { alpha }\end{array}$ & $\begin{array}{l}\text { Transcriptional coactivator, regulates genes involved in } \\
\text { energy metabolism }\end{array}$ \\
\hline PRPH (163) & Peripherin & Cytoskeletal protein \\
\hline SMN1(164) & Survival of motor neuron 1 & mRNA processing \\
\hline SPAST (165-167) & Spastin & Microtubule function \\
\hline SS18L1 (168-169) & $\begin{array}{l}\text { Synovial sarcoma translocation gene on chromosome } \\
\text { 18-like } 1\end{array}$ & Neuronal chromatin-remodeling, neurite outgrowth \\
\hline TAF15 (94) & TATA box binding protein (TBP)-associated factor & RNA polymerase II gene transcription \\
\hline TMEM106B(170-171) & Transmembrane protein 106B & $\begin{array}{l}\text { Lysosomal trafficking, dendrite morphogenesis and } \\
\text { maintenance }\end{array}$ \\
\hline
\end{tabular}




\begin{tabular}{|l|l|l|}
\hline Gene & Protein & Function \\
\hline TREM2(172) & Triggering receptor expressed on myeloid cells 2 & Immune system regulation \\
\hline UNC13A(173-174) & Unc-13 homolog A & Synaptic neurotransmitter release \\
\hline VEGF(175) & Vascular endothelial growth factor & Vasculogenesis and angiogenesis factor \\
\hline ZNF512B(176-177) & Zinc finger protein 512B & Regulation of transcription \\
\hline
\end{tabular}

